\title{
Retinoic Acid Uses Divergent Mechanisms to Activate or Suppress Mitogenesis in Rat Aortic Smooth Muscle Cells
}

\author{
Songcang Chen and David G. Gardner \\ Metabolic Research Unit and Department of Medicine, University of California at San Francisco, San Francisco, California 94143
}

\begin{abstract}
In different experimental models, retinoid has been shown to stimulate or suppress mitogenesis in cultured cells. The mechanisms underlying this seemingly paradoxical activity remain only partially understood. We have examined the ability of all-trans retinoic acid (ATRA), as well as a number of synthetic retinoids, either alone or in the presence of a mitogenic stimulus (i.e., endothelin), to regulate DNA synthesis and cell replication in cultured rat aortic smooth muscle cells. ATRA alone stimulates $\left[{ }^{3} \mathrm{H}\right]$ thymidine incorporation (approximately twofold) and increases cell number (approximately twofold) in these cultures but suppresses $\left[{ }^{3} \mathrm{H}\right]$ thymidine incorporation and reduces cell number in cultures treated with endothelin. The reduction in endothelin-stimulated DNA synthesis correlates closely with the ability of ATRA to inhibit endothelin-stimulated extracellular signal-regulated kinase but not c-Jun $\mathrm{NH}_{2}$-terminal kinase activity. Activation of mitogenesis, seen in the presence of ATRA alone, was independent of extracellular signalregulated kinase activation but correlated well with increased expression of cyclin D1 mRNA and protein. Concomitant activation of the cdk inhibitor p21 led to truncation of ATRA's mitogenic activity at higher doses of ligand. Collectively, these data indicate that the role of retinoids in the regulation of mitogenesis in vascular smooth muscle is complex. Under quiescent conditions they activate mitogenesis, while in the presence of growth stimulation, as is frequently seen with vasculopathic conditions, they suppress mitogenesis. It appears that independent circuitry is involved in signaling each of these effects. (J. Clin. Invest. 1998. 102:653662.) Key words: rat aortic smooth muscle cells $\bullet$ retinoic acid - mitogenesis - extracellular signal-regulated kinase • cell cycle
\end{abstract}

\section{Introduction}

Retinoids and their parent compound retinol (vitamin A) have been shown to play an important role in the control of growth and differentiation in the cardiovascular system. Both chronic

Address correspondence to David G. Gardner, Box 0540, Metabolic Research Unit, University of California at San Francisco, San Francisco, CA 94143. Phone: 415-476-2729; FAX: 415-476-1660; E-mail: gardner@itsa.ucsf.edu

Received for publication 19 March 1998 and accepted in revised form 22 June 1998.

J. Clin. Invest.

(C) The American Society for Clinical Investigation, Inc. 0021-9738/98/08/0653/10 \$2.00

Volume 102, Number 4, August 1998, 653-662

http://www.jci.org vitamin A deficiency (1) and embryonic deletion of selected retinoid receptors (2-6) have been associated with a variety of malformations in the heart and great vessels. Substantially less is known about the role of retinoids in the regulation of cardiovascular growth and hypertrophy after development. We (7) and others (8) have shown that all-trans retinoic acid (ATRA) ${ }^{1}$ has antihypertrophic activity in a cultured neonatal rat cardiac myocytes. ATRA has also been shown to suppress plateletderived growth factor (PDGF-BB)-dependent mitogenesis in cultured adult rat aortic smooth muscle cells (9). These latter properties have aroused interest in the retinoids as potential therapeutic agents for use in management of hyperproliferative/hypertrophic disorders of the vascular wall (e.g., atherosclerosis, restenosis after angioplasty, and hypertension).

Similar retinoid-dependent antimitogenic activity in other cell types has resulted in their use clinically in the management of selected human cancers (10), as well as hyperproliferative disorders of the epidermis (e.g., psoriasis) (11). The mechanism(s) underlying ATRA's hypoproliferative activity have been explored in some detail and several possibilities have been advanced to account for the reduction in mitogenic activity, including inhibition of cyclin D expression $(12,13)$ and activation of the cdk inhibitor $\mathrm{p} 21^{\text {Sdi1/Cip1/Waf1 }}(14,15)$. It is noteworthy, that ATRA, in some circumstances, stimulates rather than suppresses mitogenesis $(16,17)$, making it difficult to assign a single mechanism to account for its growth-regulatory properties.

Receptors for ATRA and the extended retinoid family fall into two major classes, the retinoic acid receptors (RAR) and the retinoid X receptors (RXR) (18). The former bind to both ATRA and its intracellular metabolite 9-cis RA, while RXR prefers 9-cis RA over ATRA (19). There are three subtypes in each receptor class (denoted $\alpha, \beta$, and $\gamma$ ). Vascular smooth muscle cells have been shown to possess five of the six subtypes (only RXR $\gamma$ is absent) (9). Although, as noted above, ATRA displays potent antimitogenic activity in rat aortic smooth muscle (RASM), it is not clear which of the nuclear receptors is involved in mediating this effect.

We have examined the effects of ATRA, as well as a number of other natural and synthetic retinoids, on DNA synthesis and cell replication in cultured RASM. Our findings indicate that ATRA has the ability to either stimulate or suppress mitogenesis in RASM, depending on the experimental paradigm, and it does so through independent signaling circuitry.

\footnotetext{
1. Abbreviations used in this paper: ATRA, all-trans retinoic acid; ERK, extracellular signal-regulated protein kinase; ET, endothelin; JNK, c-Jun $\mathrm{NH}_{2}$-terminal kinase; MAPK, mitogen-activated protein kinase; MEK, highly specific ERK kinase; RAR, retinoic acid receptor; RASM, rat aortic smooth muscle cells; RXR, retinoid X receptor; TTNPB, ethyl- $p$-[(E)-2-(5,6,7,8-tetrahydro-5,5,8,8-tetramethyl-2-naphthyl)-1-propenzyl] benzoic acid.
} 


\section{Methods}

Materials. $\left[{ }^{3} \mathrm{H}\right]$ Thymidine, $\left[\alpha^{-32} \mathrm{P}\right] \mathrm{dCTP}$, and $\left[\gamma_{-}{ }^{32} \mathrm{P}\right] \mathrm{ATP}$ were purchased from Dupont/New England Nuclear Research Products (Boston, MA). The luciferase assay kit and CellTiter $96 \mathrm{AQ}_{\text {ueous }}$ nonradioactive cell proliferation assay kit were purchased from Promega Biotec (Madison, WI). Mouse cyclin D1 cDNA was generously provided by Dr. C. Sherr (St. Jude Children's Research Hospital, Memphis, TN). WWP-p21-luc was a gift of Dr. Leonard Freedman (Memorial Sloan Kettering Cancer Center, New York). ET-1 was purchased from Peninsula Laboratories, Inc. (Belmont, CA); PD098059 was from Research Biochemicals International (Natick, MA). Anti-ERK2 (C-14), anti-JNK1 (C-17), anti-cylin D1 (R-124), and anti-p21 (F-5) antibodies were obtained from Santa Cruz Biotechnology, Inc. (Santa Cruz, CA). Bovine myelin basic protein was from Upstate Biotechnology, Inc. (Lake Placid, NY). The RNeasy mini kit was purchased from QIAGEN Inc. (Santa Clara, CA). Alltrans retinoic acid (ATRA) was obtained from Sigma Chemical Co. (St. Louis, MO). 9-cis RA, LG100153 (an RXR-selective agonist), and ethyl- $p$-[(E)-2-(5,6,7,8-tetrahydro-5,5,8,8-tetramethyl-2-naphthyl)1-propenzyl] benzoic acid (TTNPB, an RAR-selective agonist) were kindly provided by Dr. Richard A. Heyman of Ligand Pharmaceuticals (San Diego, CA). Other reagents were obtained through standard commercial suppliers.

Cell culture. Neonatal RASM cells were obtained at passage 19 from Dr. H. Ives at University of California, San Francisco. Cells were cultured at $37^{\circ} \mathrm{C}$ in a $5 \% \mathrm{CO}_{2}$-humidified incubator in DME supplemented with $10 \%$ FBS, $100 \mathrm{U} / \mathrm{ml}$ penicillin, $100 \mathrm{mg} / \mathrm{ml}$ streptomycin, and $2 \%$ ( vol $/ \mathrm{vol}$ ) broth, tryptose phosphate (growth media). Cells were used after reaching $75-80 \%$ confluence at passage 21-30.

$\left[{ }^{3} H\right]$ Thymidine incorporation. Cells were cultured in growth media (described above) in 24-well plates. Cells were then either continued in the growth media or changed to serum-substitute media (20) for the ensuing 24-h period. At that point, all cells were placed in serum substitute media and treated with different concentrations of ATRA, one of the retinoid analogues, or vehicle for the next $48 \mathrm{~h}$. Where indicated, endothelin-1 (ET) was included for the final $24 \mathrm{~h}$ of culture. $4 \mathrm{~h}$ before collection, cells were pulsed with $\left[{ }^{3} \mathrm{H}\right]$ thymidine $(1 \mu \mathrm{Ci} /$ well $)$ in modified Eagle's medium (MEM) with Earle's balanced salt solution and the same additives used in the prepulse period. Cells were then washed three times with PBS and lysed in the presence of $10 \%$ TCA at $4^{\circ} \mathrm{C}$ for $30 \mathrm{~min}$. Cellular residues were rinsed in $95 \%$ ethanol, solubilized in $0.25 \mathrm{~N} \mathrm{NaOH}$ at $4^{\circ} \mathrm{C}$ for $2 \mathrm{~h}$, and then neutralized with $2.5 \mathrm{M} \mathrm{HCl} / 1 \mathrm{M}$ Tris- $\mathrm{HCl}(\mathrm{pH} 7.5)$. Radioactivity was measured by liquid scintillation spectrophotometry.

Cell proliferation assay. Cell density was deterimined by the CellTiter $96 \mathrm{AQ}_{\text {ueous }}$ nonradioactive cell proliferation assay kit. The kit contains a colorimetric reagent, 3-(4,5-dimethylthiazol-2-yl)-5-(3-carboxymethoxyphenyl)-2-(4-sulfophenyl)-2H-tetrazolium salt (MTS), that is selectively taken up and converted to soluble formazan (dark blue in color) through dehydrogenase enzymes produced by metabolically active, proliferating cells. The absorbance at $490 \mathrm{~nm}$ is directly proportional to the number of living cells in the culture. RASM cells were cultured in 96-well plates and growth arrested in serum substitute/DME for $24 \mathrm{~h}$. The quiescent cells were treated with different concentrations of ATRA for $48 \mathrm{~h}$ in the presence or absence of ET-1 for the final $24 \mathrm{~h}$ of culture. To terminate the experiment, MTS solution was added to each well according to the instructions provided by the manufacturer and then incubated for 2-4 h. Absorbance at 490 $\mathrm{nm}$ was measured on a multiwell scanning spectrophotomer (microplate EL 310; Bio-Tek Instruments, Winooski, VT).

RNA isolation and Northern blot analysis. Cells were cultured in growth medium, then changed to DME/serum substitute for $24 \mathrm{~h}$. At that point, they were treated with different concentrations of ATRA, or one of the synthetic retinoids, for defined periods of time. Total RNA was isolated from cells using the RNeasy minikit according to the instructions provided by the manufacturer. $20 \mu \mathrm{g}$ of RNA was separated on a gel containing $2.2 \%$ formaldehyde, transferred to a ni- trocellulose filter, and hybridized with a ${ }^{32} \mathrm{P}$-labeled 1.2-kb mouse cyclin D1 cDNA (21), isolated as a EcoR1 fragment. The membranes were subsequently stripped and rehybridized with a ${ }^{32} \mathrm{P}$-labeled $1.3-$ kb glyceraldehyde-3-phosphate dehydrogenase cDNA (22) to permit normalization among samples for differences in RNA loading and/or transfer to the filter. Autoradiographic signals were quantified using National Institutes of Health Image.

Transfection and luciferase assay. Cells were transfected by electroporation (Gene Pulsar, Bio-Rad Laboratories, Hercules, CA) at $250 \mathrm{~V}$ and $960 \mu \mathrm{F}$ using $2 \mu \mathrm{g}$ of WWP-p21-Luc reporter per transfection. After transfection, cells were plated in six-well plates at a density of $1 \times 10^{6}$ cells/well in growth media for $24 \mathrm{~h}$. Medium was then changed to DME/serum substitute for the ensusing $24 \mathrm{~h}$, at which point different concentrations of ATRA were added. Cells were collected and cellular extracts were generated as described previously (23). Extract protein concentration was measured using the Coomassie protein reagent (Pierce Chemical Co., Rockford, IL). Equivalent amounts of lysate protein were then assayed for luciferase activity.

Immunoprecipitation and kinase assay. Cells were treated with the agents indicated for different time intervals. Cells were washed twice with PBS and scraped into $0.8 \mathrm{ml}$ of lysis buffer $(50 \mathrm{mM}$ Tris$\mathrm{HCl}, \mathrm{pH}$ 7.5, $150 \mathrm{mM} \mathrm{NaCl}, 1 \%$ Triton X-100, 5 mM EDTA, $1 \mathrm{mM}$ EGTA, $10 \%$ glycerol, $1 \mathrm{mM}$ PMSF, $1 \mathrm{mM}$ DTT, $1 \mathrm{mM}$ sodium orthovanadate, $10 \mathrm{mM}$ sodium fluoride, $1 \mathrm{mM}$ glycerophosphate, $2 \mu \mathrm{g} / \mathrm{ml}$ aprotinin, $1 \mu \mathrm{g} / \mathrm{ml}$ pepstatin, $1 \mu \mathrm{g} / \mathrm{ml}$ leupeptin). The lysates were clarified by centrifugation in a benchtop centrifuge at 15,000 rpm for $10 \mathrm{~min}$ at $4^{\circ} \mathrm{C}$. $200 \mu \mathrm{g}$ of supernatant protein was incubated with $1 \mu \mathrm{g}$ of anti-ERK2 or anti-JNK1 antibody and $10 \mu \mathrm{l}$ of protein G-Sepharose for $1-2 \mathrm{~h}$ at $4^{\circ} \mathrm{C}$. Immunoprecipitates were washed three times with lysis buffer and once with kinase buffer (25 mM Hepes, $\mathrm{pH} 7.4$; $10 \mathrm{mM} \mathrm{MgCl} 2,10 \mathrm{mM} \mathrm{MnCl}_{2}, 1 \mathrm{mM}$ DTT) without ATP. After washing, the immunoprecipitates were resuspended in $30 \mu \mathrm{l}$ of kinase buffer containing $20 \mu \mathrm{M}$ ATP, $4 \mu \mathrm{Ci}\left[\gamma^{-32} \mathrm{P}\right] \mathrm{ATP}$, and $20 \mu \mathrm{g}$ myelin basic protein (MBP) or $5 \mu \mathrm{g}$ glutathione $S$-transferase-c-Jun (GSTc-JUN), for measurements of extracellular signal-regulated protein kinase (ERK) or c-Jun $\mathrm{NH}_{2}$-terminal kinase (JNK) activity, respectively, and incubated at $30^{\circ} \mathrm{C}$ for $20 \mathrm{~min}$. The samples were electrophoresed on $15 \%$ SDS-polyacrylamide gels, which were then dried and exposed to $\mathrm{x}$-ray film. Phosphorylation of each substrate protein was quantitated by densitometric scanning of the autoradiographs.

Immunoblot analysis. Cell lysates $(30 \mu \mathrm{g}$ soluble protein for cyclin D1, $100 \mu \mathrm{g}$ for $\mathrm{p} 21)$ were subjected to $12.5 \%$ SDS-PAGE and transferred onto nitrocellulose membranes (Amersham Chemical Corp., Amersham, IL). The membranes were blocked with 5\% nonfat milk in $50 \mathrm{mM}$ Tris- $\mathrm{HCl}, \mathrm{pH} 7.5,150 \mathrm{mM} \mathrm{NaCl}, 0.1 \%$ Tween 20 (TBST) and probed with anti-cyclin D1 (diluted 1:100 in TBST) or anti-p21 (diluted 1:50 in TBST) antibody. A horseradish peroxidase-conjugated second antibody (diluted 1:2,000 in TBST) was employed to detect immunoreactive bands using the enhanced chemiluminescence (ECL) Western blotting detection system (Amersham Chemical Corp.).

Statistical analysis. Data were evaluated using one-way ANOVA with Newman-Keuls test for significance.

\section{Results}

We examined the ability of ATRA to promote incorporation of $\left[{ }^{3} \mathrm{H}\right]$ thymidine into RASM, in the presence or absence of endothelin $\left(10^{-7} \mathrm{M}\right)$. Since previous studies have suggested that the growth status (i.e., quiescent vs. nonquiescent) of RASM cultures may affect the direction of the mitogenic response to certain ligands (e.g., vitamin D) (24), we carried out these studies with or without a $24-\mathrm{h}$ "deinduction" in DME/serum substitute media. As Fig. 1 shows, ATRA alone effected a significant increase (maximal two- to threefold induction) in $\left[{ }^{3} \mathrm{H}\right]$ thymidine incorporation. Interestingly, the lower concen- 


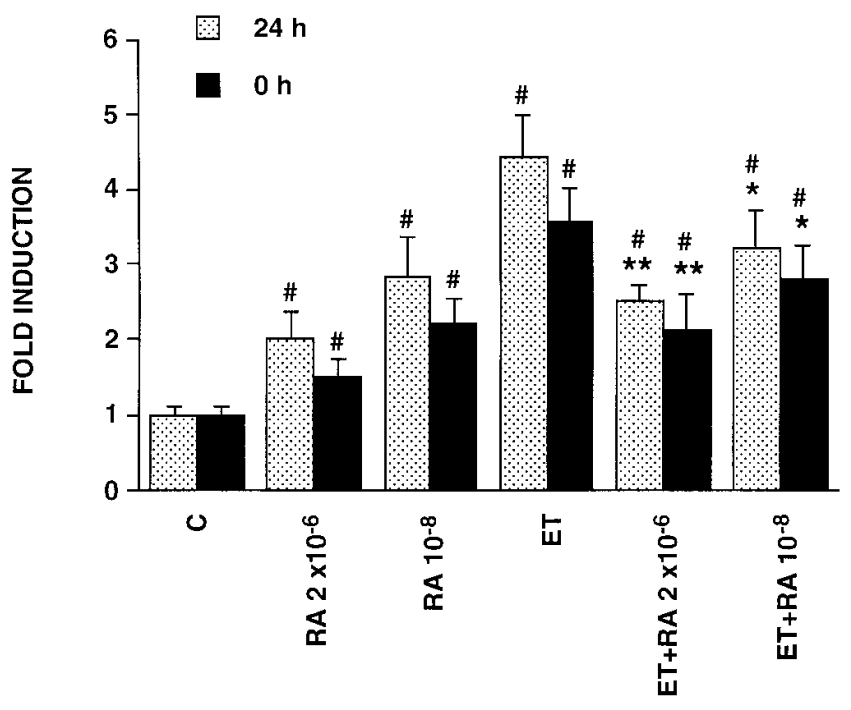

Figure 1. Effect of ATRA on basal and ET-stimulated DNA synthesis in RASM cells. Cells were grown in DME $/ 10 \%$ EC to $~ 75-80 \%$ confluence then changed to either fresh DME $/ 10 \% \mathrm{EC}(0 \mathrm{~h})$ or DME/serum substitute $(24 \mathrm{~h})$ and incubated for an additional $24 \mathrm{~h}$. Media in all cultures was then changed to DME/serum substitute, and the cells were exposed to the indicated concentrations of ATRA for the next $48 \mathrm{~h}$. Where indicated, ET $\left(10^{-7} \mathrm{M}\right)$ was included for the final $24 \mathrm{~h}$ of the incubation. $4 \mathrm{~h}$ before collection, cells were pulsed with $1 \mu \mathrm{Ci}\left[{ }^{3} \mathrm{H}\right]$ thymidine in MEM Eagle's medium containing Earle's balanced salt solution. $\left[{ }^{3} \mathrm{H}\right]$ Thymidine incorporation was assayed as described in Methods. Data are expressed as means \pm SD $(n=5) .{ }^{\#} P<0.01$ vs. control; $* P<0.05, * * P<0.01$ vs. ET alone.

tration of ATRA $\left(10^{-8} \mathrm{M}\right)$ was more effective than the higher concentration $\left(2 \times 10^{-6} \mathrm{M}\right)$ in effecting this increase. Endothelin, a vasoconstrictor peptide with potent mitogenic activity in vascular smooth muscle cells $(25,26)$, promoted an even larger increase in $\left[{ }^{3} \mathrm{H}\right]$ thymidine incorporation (maximal four- to fivefold induction). Paradoxically, combined treatment with both ATRA and ET led to a reduction in $\left[{ }^{3} \mathrm{H}\right]$ thymidine incorporation relative to that seen with ET alone. Levels, in fact, approached those seen with ATRA alone. Preincubation of the cells in DME/serum substitute for $24 \mathrm{~h}$ led to slightly

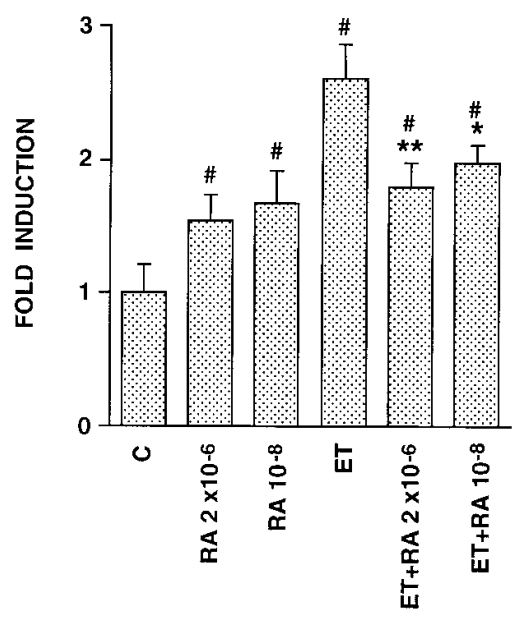

Figure 2. ATRA inhibits RASM cell proliferation in the presence or absence of ET. Cells were grown to $75-80 \%$ confluence in 96-well plates, then placed in DME/serum substitute for $24 \mathrm{~h}$. Individual wells were then treated with the indicated concentrations of ATRA for $48 \mathrm{~h}$. Where indicated ET $\left(10^{-7} \mathrm{M}\right)$ was included for the final $24 \mathrm{~h}$ of incubation. Cell number was assessed using the technique described in

Methods. Data represent the means \pm SD from four independent experiments. ${ }^{\#} P<0.01$ vs. control; ${ }^{*} P<0.05,{ }^{* *} P<0.01$ vs. ET alone. higher levels of $\left[{ }^{3} \mathrm{H}\right]$ thymidine incorporation under all conditions tested (vs. cells cultured in serum) but did not alter the qualitative nature of the response. All subsequent experiments were carried using the $24-\mathrm{h}$ preincubation period in DME/serum substitute.

The effects on DNA synthesis were mirrored at the level of cell replication. As Fig. 2 shows, cell numbers increased after treatment with ATRA or ET, although, in this instance, the dose dependence of the ATRA effect was less apparent. As noted in the $\left[{ }^{3} \mathrm{H}\right]$ thymidine incorporation studies above, the combination of ATRA and ET led to a reduction in the ETdependent increment in cell number. Thus, perturbations in DNA synthesis in this particular setting are largely reflective of changes in cell number.

ET has been shown to signal at least a portion of its biological activity through the mitogen-activated protein kinases (MAPKs) (27). Included within the extended MAPK family are the ERKs, which function as downstream effectors of growth factor receptors, and the JNKs, which are typically acti-

A

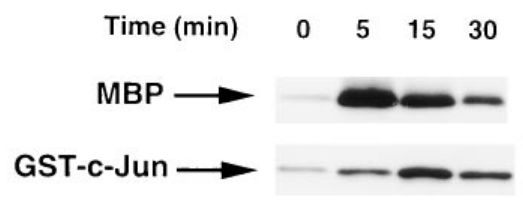

B

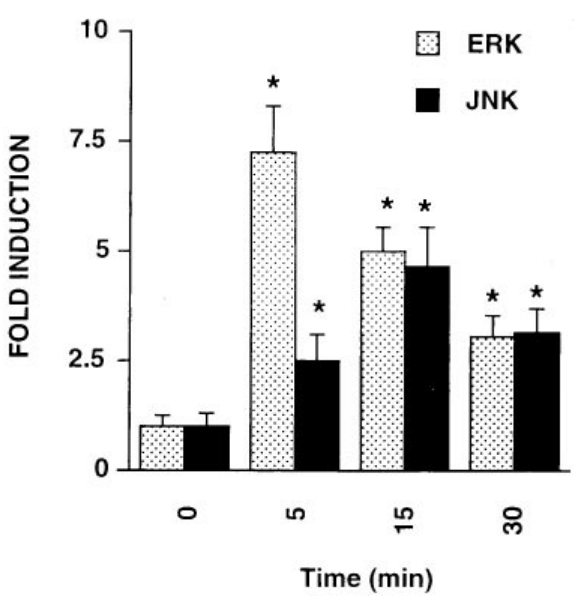

Figure 3. ET stimulates ERK and JNK activity in RASM cells. Cells were cultured in DME/serum substitute for $24 \mathrm{~h}$, then exposed to ET $\left(10^{-7} \mathrm{M}\right)$ for the intervals indicated. Cells were lysed and lysates were immunoprecipitated with anti-ERK2 or anti-JNK2 antibody. ERK and JNK activities were measured in an in vitro kinase assay using MBP and GST-c-JUN as subtrates, respectively. Radiolabeled products were then separated by SDS/PAGE. Representive experiments are shown in $A$. Autoradiographic signals were then quantitated using NIH Image. Pooled data, derived from three separate experiments, are presented in $B .{ }^{*} P<0.01$ vs. control. 
vated by cellular stresses like cytokine stimulation and ultraviolet irradiation (28). Thus, we examined the ability of ET to activate either ERK or JNK activity in our RASM cultures. ET effected almost a sevenfold increment in ERK activity in RASM cells. This response peaked at $5 \mathrm{~min}$ but remained elevated $30 \mathrm{~min}$ after administration of the peptide (Fig. 3). JNK activity was also stimulated by ET. In this instance, the maximal response was lower than that seen with ERK (maximal induction of approximately four- to fivefold) and the peak was somewhat delayed, occurring $15 \mathrm{~min}$ after administration of the peptide. Once again, JNK activity remained elevated throughout the 30-min time course of the experiment.

Next, we asked whether activation of the ERK pathway might be linked to ET's mitogenic activity in these RASM cultures. To examine this question, we used the highly specific ERK kinase (i.e., MEK) inhibitor PD098059 to selectively suppress the MEK/ERK cascade. As shown in Fig. 4, $A$ and $B$, PD098059 effected a dose-dependent reduction in ET-stimulated, but not basal, ERK activity. It had no effect on either basal or ET-stimulated JNK activity. Treatment with PD098059 also led to a dose-dependent reduction in ET-stimulated DNA synthesis in these cultures (Fig. 4 C). Once again the MEK inhibitor had no effect on basal $\left[{ }^{3} \mathrm{H}\right]$ thymidine incorporation. By inference, the ability of ET to stimulate DNA synthesis in these cultured RASM cells appears to be closely related to its ability to activate the MEK/ERK pathway.

We next asked whether the mitogenic effect of ATRA might also be mediated through activation of the ERK cascade. We examined the ability of PD098059 to inhibit ATRAdependent $\left[{ }^{3} \mathrm{H}\right]$ thymidine incorporation in RASM cells. As Fig. 5 shows, PD098059 did not alter the predicted two- to threefold induction of $\left[{ }^{3} \mathrm{H}\right]$ thymidine incorporation seen with ATRA (compare with Fig. 1). Nor did it seem to alter the RAdependent suppression of ET-stimulated DNA synthesis. When ERK and JNK were looked at directly, ATRA had no effect on either activity when used alone (Fig. 6). Similarly, ATRA had no effect on ET-stimulated JNK activity; however, it effected a dose-dependent suppression of ET-stimulated ERK activity. Upon reexamining the data in Fig. 5, it appears likely that PD098059 did, in fact, suppress ET-stimulated $\left[{ }^{3} \mathrm{H}\right]$ thymidine incorporation. In this instance the observed residual activity, particularly at the lower concentration of ATRA, presumably reflects the ERK-independent stimulatory activity of the ligand.

ATRA is capable of interacting with either the retinoic acid receptor ( $R A R$ ) or the retinoid $X$ receptor (RXR) in target cells as a means of promoting its biological activity (18). We used synthetic RAR- or RXR-selective ligands in an effort to determine whether the effects observed above were signaled by one or both of these receptors. Neither the RAR(i.e., TTNPB) nor the RXR-selective (LG100153) ligand had any effect on basal ERK or JNK activity (Fig. 7). Neither did they affect ET-stimulated JNK activity; however, each of these compounds brought about a reduction in ET-stimulated ERK activity. On a molar basis, the RAR-selective analogue appeared to be more potent than its RXR-selective counterpart.

As noted above with ATRA, each of the RAR- and RXRselective agonists, as well as 9-cis RA, promoted an increase in $\left[{ }^{3} \mathrm{H}\right]$ thymidine incorporation in RASM cells (Fig. 8). Once again, lower concentrations of these ligands $\left(10^{-8}-10^{-9} \mathrm{M}\right)$ were more effective than higher concentrations $\left(2 \times 10^{-6} \mathrm{M}\right)$ in promoting this increase; however, much lower concentrations
A

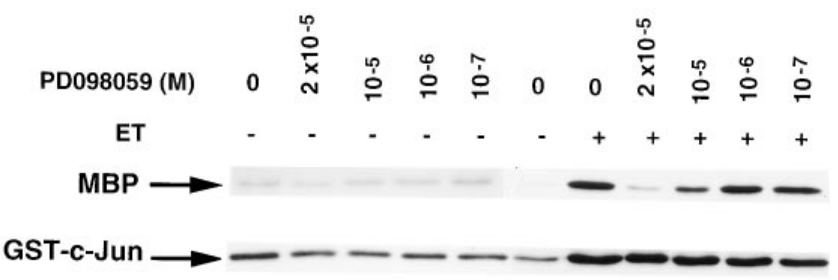

B

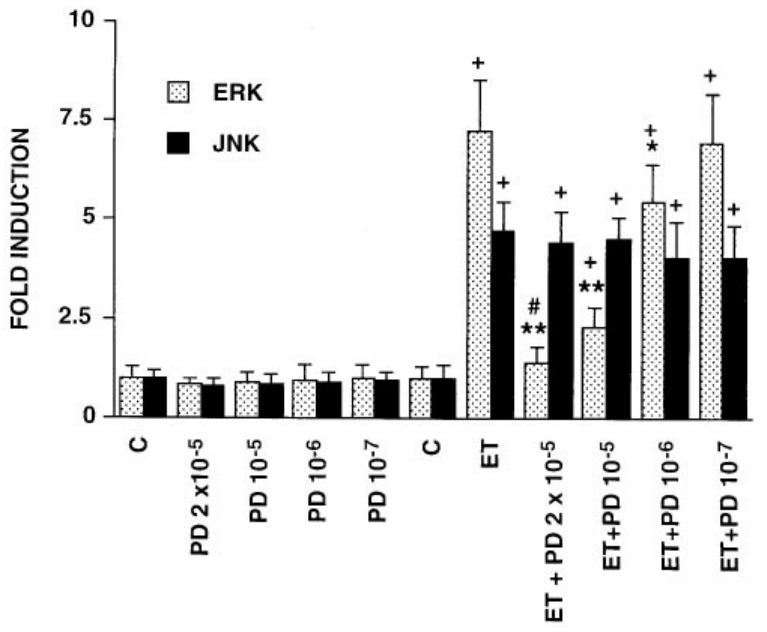

C

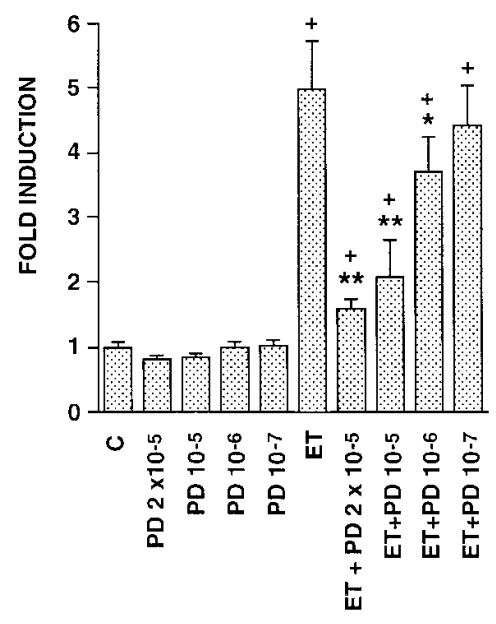

Figure 4. PD098059 inhibits both ET-stimulated ERK activity and ET-dependent $\left[{ }^{3} \mathrm{H}\right]$ thymidine uptake in RASM cells. Cultures were grown to $75-80 \%$ confluence, then placed in DME/serum substitute for $24 \mathrm{~h}$ as described in Fig. 3. Individual cultures were pretreated with the indicated concentrations of PD098059 for $1 \mathrm{~h}$ and then treated with vehicle or ET $\left(10^{-7} \mathrm{M}\right)$ for 5 min, $15 \mathrm{~min}$, or $24 \mathrm{~h}$ for measurement of ERK activity, JNK activity or DNA synthesis, respectively. Individual assays and data analysis were

carried out as described in Figs. 1 and 3. Representative measurements of ERK and JNK activity are shown in $A$ and pooled data $(n=$ 3 ) for these measurements are presented in $B$. Pooled data $(n=4)$ for measurements of $\left[{ }^{3} \mathrm{H}\right]$ thymidine incorporation are shown in $C$. ${ }^{*} P<0.05,{ }^{* *} P<0.01$ vs. ET alone; ${ }^{\#} P<0.05,{ }^{+} P<0.01$ vs. control. 


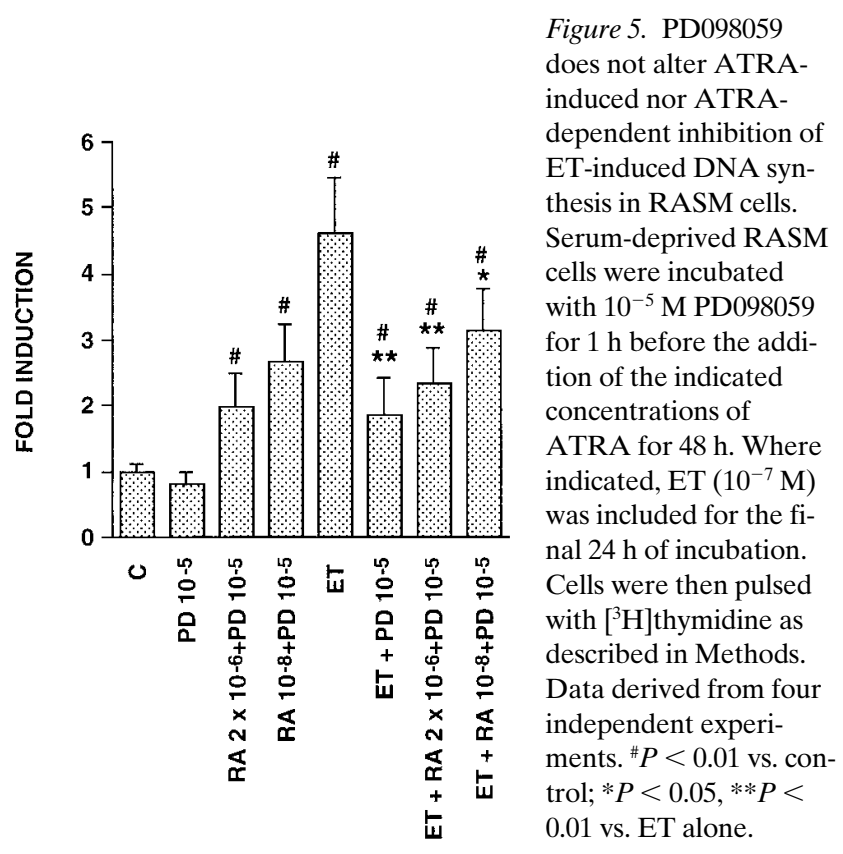

of ligand $\left(10^{-10} \mathrm{M}\right)$ showed diminished efficacy implying a concentration threshold for demonstration of the effect. In the presence of ET, all ligands inhibited $\left[{ }^{3} \mathrm{H}\right]$ thymidine incorporation, and in each instance the higher dose of ligand was more effective than the lower dose in effecting the reduction. There was no evidence for synergism between the RXR- and RARselective ligands over a broad range of ligand concentration.

Collectively these data imply that both RAR and RXR, presumably in their respective liganded forms, independently stimulate basal mitogenic activity yet suppress ET-stimulated mitogenesis in cultured RASM cells. The latter effect appears to derive, at least in part, from suppression of ET-dependent ERK activity, but the former cannot be explained through activation of the ERK or the JNK pathways. To explore this further, we turned our attention to the cell cycle machinery itself in an attempt to identify the locus of the retinoic acid/retinoid effect. Cyclin D1, through interaction with the G1 cyclin-dependent kinases (e.g., cdk 4), is a key regulator of entry into the cell cycle at the G0/G1 interface (29), and this represents a logical target for mitogenic control. We examined the effects of ATRA on cyclin D1 mRNA levels in RASM. As Fig. $9 A$ shows, both $10^{-8}$ and $2 \times 10^{-6} \mathrm{M}$ ATRA led to a three- to fourfold increment in cyclin D1 transcript levels. This effect peaked after $12 \mathrm{~h}$ of exposure to the ligand and remained elevated for the ensuing $36 \mathrm{~h}$; Western blot analysis of cyclin D1 protein levels (Fig. $9 \mathrm{C}$ ) provided similar findings. In this instance the increment was first apparent after $24 \mathrm{~h}$ of ligand treatment, reflecting the anticipated lag between mRNA production and new protein synthesis, and peaked at 36-48 h. While the higher concentration of ATRA appeared to be slightly more effective in increasing cyclin D1 mRNA levels, this difference was not readily apparent at the level of the cyclin D1 protein.

Extending the analysis to the synthetic analogues, we found that both the RAR- and the RXR-selective ligands stimulated cyclin D1 mRNA levels in these cultures (Fig. 10), implying that, as with the inhibitory activity noted above, either of these
A

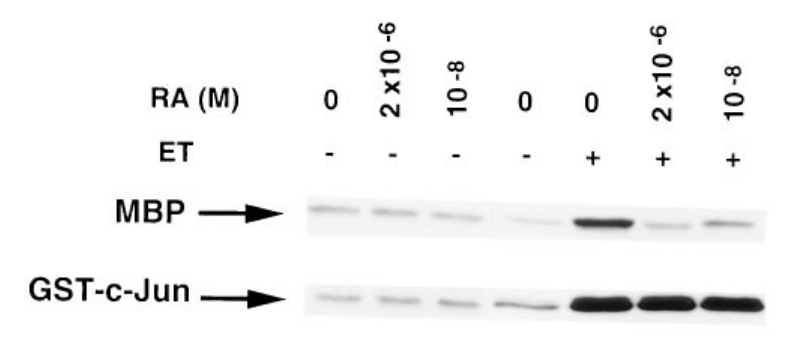

B

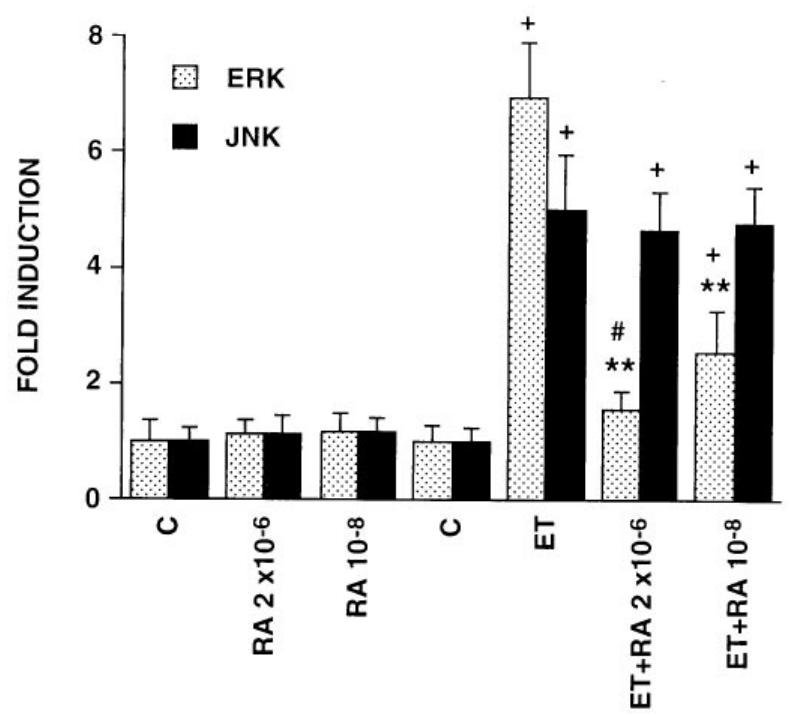

Figure 6. Effect of ATRA on basal and ET-stimulated ERK and JNK activities. Cells were cultured and treated with ATRA and ET, and ERK and JNK assays were carried out as described in Fig. 3. Representative autoradiograms are shown in $A$. Data derived from four independent experiments are presented in $B . * * P<0.01$ vs. ET alone; ${ }^{\#}<0.05,{ }^{+} P<0.01$ vs. control.

nuclear receptor ligands is capable of stimulating DNA synthesis in cultured RASM cells. ET, on the other hand, had no effect on cyclin D1 transcript levels, nor did it affect the induction seen after administration of all trans-RA (Fig. 11).

The near equivalence of the induction of cyclin D1 by $10^{-8}$ vs. $2 \times 10^{-6} \mathrm{M}$ ATRA fails, however, to account for the difference in their respective abilities to increase $\left[{ }^{3} \mathrm{H}\right]$ thymidine incorporation in RASM (see Fig. 1). As noted above, expression of the cdk inhibitor p21 has been shown to be upregulated by retinoic acid/retinoids in a number of different contexts (14, 15). With this in mind, we asked whether ATRA might also activate p21 expression in cultured RASM cells as a means of suppressing mitogenic activity. As Fig. $12 \mathrm{~A}$ shows, ATRA at the higher $\left(2 \times 10^{-6} \mathrm{M}\right)$ but not the lower $\left(10^{-8} \mathrm{M}\right)$ concentration effected more than a threefold increment in p21 protein levels in these cells. Similar findings were observed when the p21 gene promoter, linked to a luciferase reporter, was introduced into these cells and, subsequently, subjected to ATRA 
A

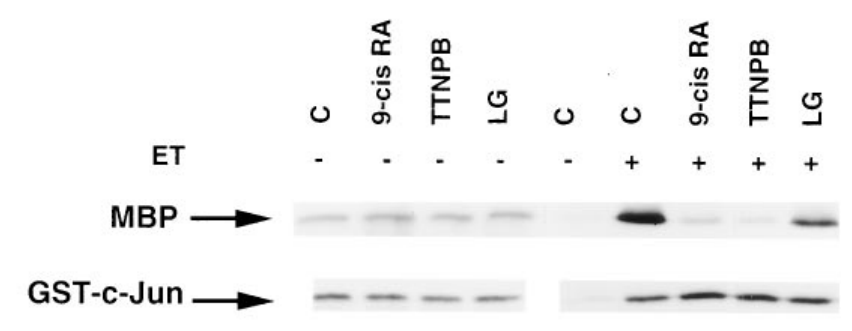

B

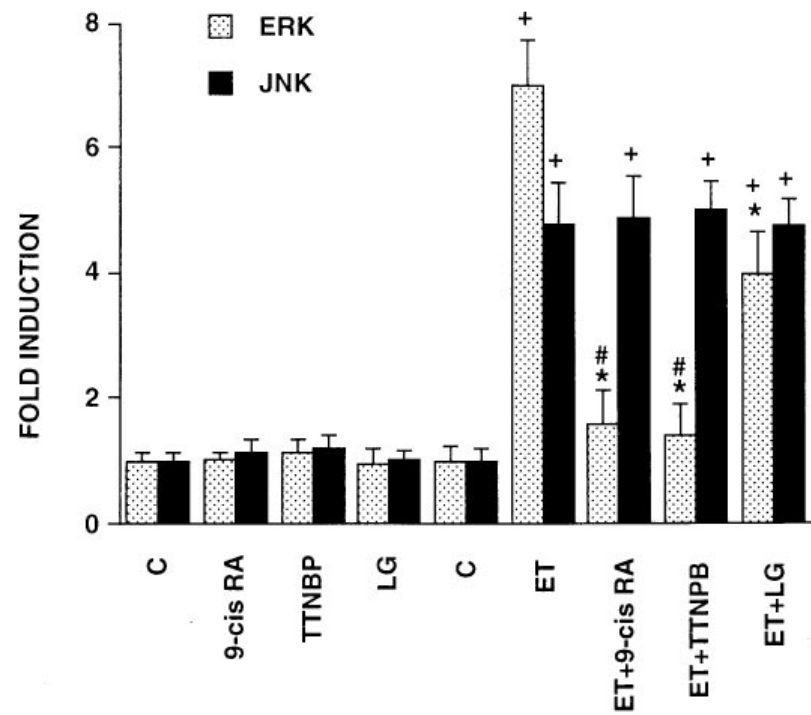

Figure 7. Effect of 9-cis RA and synthetic RA agonists on ERK and JNK activities with or without ET stimulation. Serum-deprived RASM cells were treated with 9-cis RA, TTNPB, or LG100153 $\left(\right.$ all $\left.2 \times 10^{-6} \mathrm{M}\right)$ for $48 \mathrm{~h}$. Where indicated, ET $\left(10^{-7} \mathrm{M}\right)$ was included for last $24 \mathrm{~h}$ of the incubation. Cells were lysed and analyses were carried out as described in Fig. 3. Representative experiments are presented in $A$. Pooled data from four independent experiments are provided in $B .{ }^{*} P<0.01$ vs. ET alone, ${ }^{\#} P<0.05,{ }^{+} P<0.01$ vs. control.

treatment (Fig. $12 \mathrm{~B}$ ). Once again the higher, but not the lower, concentration of ATRA stimulated 21 promoter activity. ET also led to a transient increase in promoter activity at $12 \mathrm{~h}$, but this quickly returned to baseline after $24 \mathrm{~h}$ of exposure. The addition of ET to ATRA ( $36 \mathrm{~h}$ of treatment) resulted in no change in promoter activity relative to that seen with ATRA alone (data not shown).

\section{Discussion}

Five significant findings emerge from this work. First, depending upon the experimental paradigm chosen for study, ATRA has the capacity to either stimulate or suppress mitogenesis in

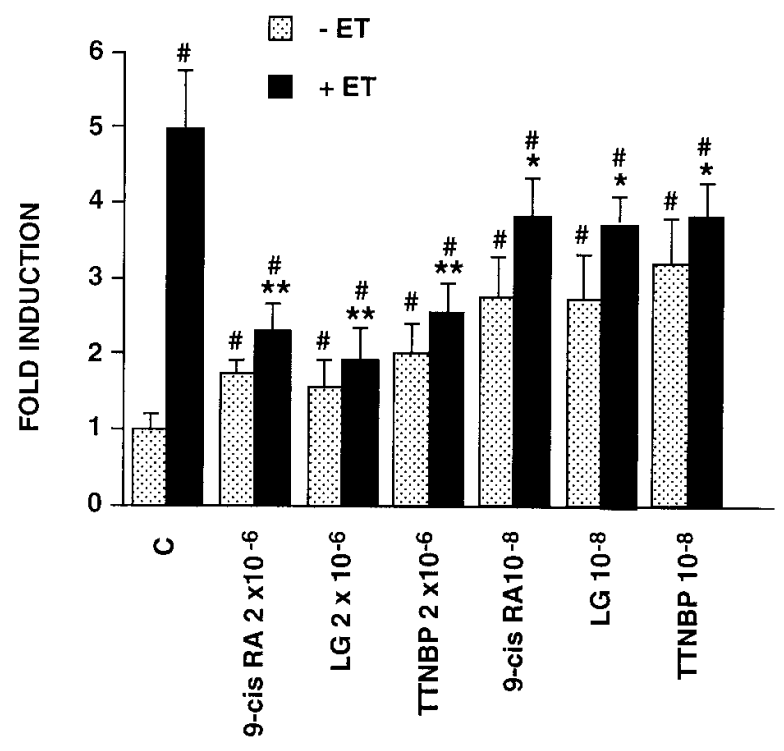

Figure 8. Effect of 9-cis RA and synthetic RA agonists on basal and ET-stimulated $\left[{ }^{3} \mathrm{H}\right]$ thymidine incorporation in RASM cells. Serumdeprived RASM cells were treated with the indicated concentrations of 9-cis RA, TTNPB and/or LG100153 for $48 \mathrm{~h}$. Where indicated ET $\left(10^{-7} \mathrm{M}\right)$ was included for the final $24 \mathrm{~h}$ of incubation. $\left[{ }^{3} \mathrm{H}\right]$ Thymidine incorporation was determined as described in Fig. 1. Data were obtained from six independent experiments. ${ }^{\#} P<0.01 \mathrm{vs.} \mathrm{control;}{ }^{*} P<$ $0.05, * * P<0.01$ vs. ET alone.

RASM cells. These properties are shared by both RAR- and RXR-selective ligands. Second, the ability of endothelin to stimulate mitogeneis in RASM cells closely parallels its ability to increase ERK activity. Third, the ability of ATRA to inhibit ET-stimulated mitogenic activity parallels its ability to reduce ERK activity. Fourth, ATRA stimulates mitogenesis without changing ERK activity. In this case, the increase in DNA synthesis appears to be related to increased expression of cyclin $\mathrm{D} 1$, a key component in the cycle machinery that is responsible for effecting entry into G1. Fifth, coincident activation of p21 expression, particularly at higher concentrations of ATRA, partially restrains the intrinsic mitogenic activity of this ligand.

To our knowledge, divergent growth effects in the same cell type have not been previously reported with ATRA. There are scattered reports of ATRA-dependent stimulation of mitogenic activity in selected cell culture systems $(16,17)$; however, the most typical effect of ATRA (or related retinoids) is inhibition of mitogenic activity. This latter response has been demonstrated in a number of transformed cell lines $(30,31)$ as well as nontransformed cells that have been preactivated (e.g., by application of serum or growth factors) to trigger an increase in mitogenic activity (9). There are relatively few studies using ATRA in quiescent cell cultures, as described in this report. Such studies take on particular relevance for vascular smooth muscle cells, which under physiological conditions may more closely resemble the quiescent rather than the growth-activated phenotype (32).

Vitamin A deficiency has been shown to result in a number of congenital malformations in the cardiovascular system. These include double-outlet right ventricle, transposition of the great vessels, tetralogy of Fallot, supracristal ventricular septal defect, and truncus arteriosus (1). Mice with homozy- 
A

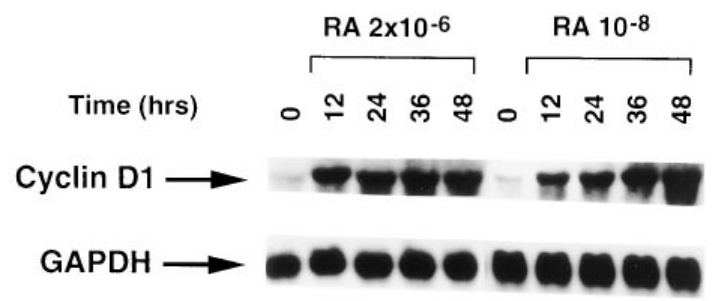

B

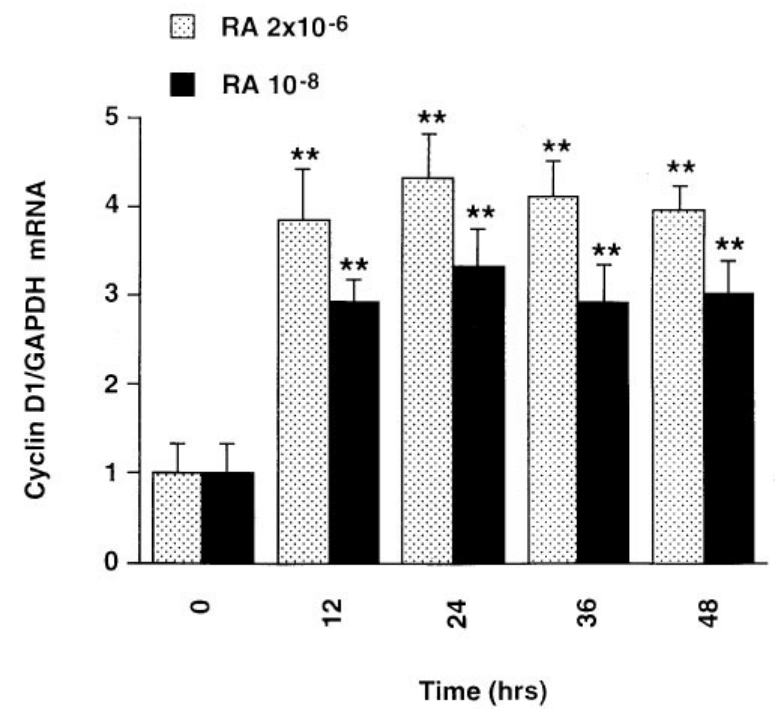

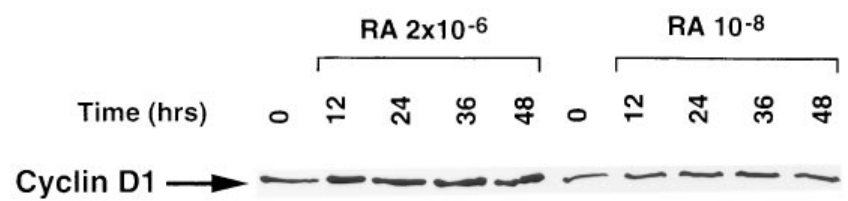

D

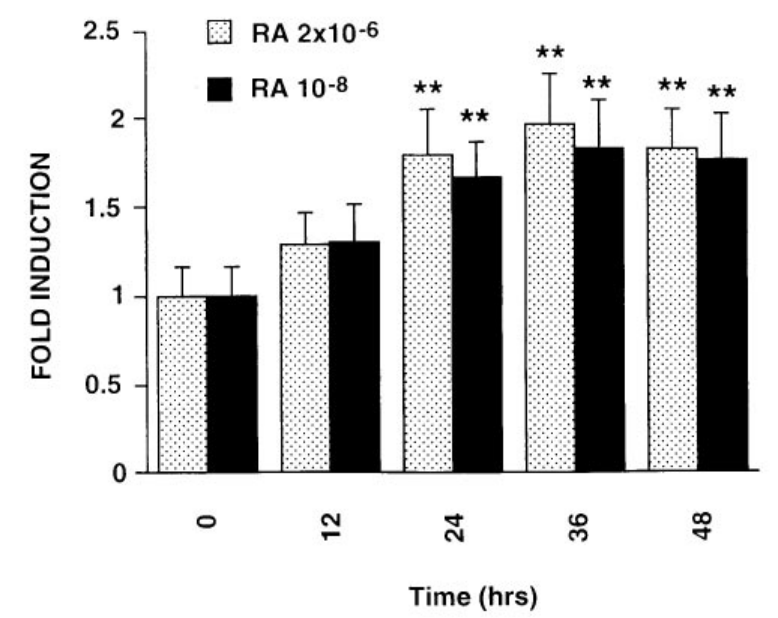

Figure 9. ATRA stimulates cyclin D1 gene expression. Quiescent RASM cells were treated with ATRA, at the concentrations indicated, for different time intervals. RNA was extracted, size fractionated on agarose gels and blot-hybridized with radiolabeled cyclin D1 or GAPDH cDNA probes as described in Methods. Representative autoradiographs are shown in $A$. Pooled data $(n=4)$ are presented as normalized cyclin D1/ GAPDH mRNA ratios in $B$. In separate experiments, cellular lysates were size-fractionated by SDS-PAGE and transferred onto membranes which were probed with antisera directed against cyclin D1. Immunoreactive bands were detected using the ECL system. Representative experiments are shown in $C$. Pooled data $(n=6)$ are presented in $D$. $* * P<0.01$ vs. control.

gous embryonic deletions of the $\operatorname{RXR}(2,5,6)$, as well as selected combinatorial deletions of the retinoic acid receptor $(3$, 4 ), display a number of cardiac abnormalities including "atrialization" of the ventricular myocardium (5) and a predisposition to malformations (6) similar to those seen with vitamin A deficiency. Collectively, these studies imply an important role for the retinoids in the morphogenetic development of the cardiovascular system. Less information is available regarding their role in the regulation of growth in the heart or vasculature postdevelopment. Zhou et al. (8) and Wu et al. (7) have independently reported that retinoids inhibit changes in gene expression and the development of morphological features typically associated with hypertrophy in a cultured neonatal rat myocyte model. Noteworthy, however, a recent publication from Colbert et al. (33) indicated that cardiac-selective expression of an activated form of RXR resulted in the development of dilated cardiomyopathy and congestive heart failure in transgenic mice. This latter study implies that retinoid effects on the myocardium in vivo are considerably more complex that the in vitro studies would imply. Miano et al. (9) recently demonstrated that most of the known RAR/RXR are present in cultured RASM. They went on to show that ATRA decreased PDGF-BB-sensitive $\left[{ }^{3} \mathrm{H}\right]$ thymidine incorporation in these cells and suggested a potential role for retinoids in the regulation of vascular smooth muscle cell hypertrophy/hyperplasia in disorders involving the vascular wall. They did not observe the promitogenic activity of ATRA alone, which we have reported here. This will obviously need to be accounted for in future evaluations of the retinoids as potential therapeutic agents.

Endothelin has been shown by a number of investigators to stimulate ERK activity $(34,35)$ and/or increase DNA synthesis $(36,37)$ in RASM cells. In fact, at least two groups, using vascular (35) and pulmonary (38) smooth muscle cells respectively, have suggested a link between ET stimulation of ERK activity and its mitogenic properties. This, of course, does not preclude independent effects of ET on other cyclins or cyclindependent kinases involved in regulating the cell cycle, but based on the studies with the PD098059 described above, such 


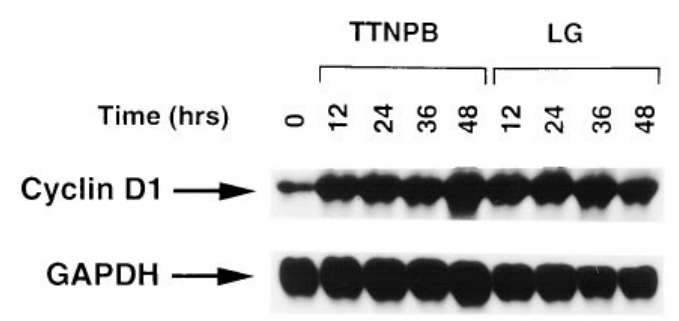

B

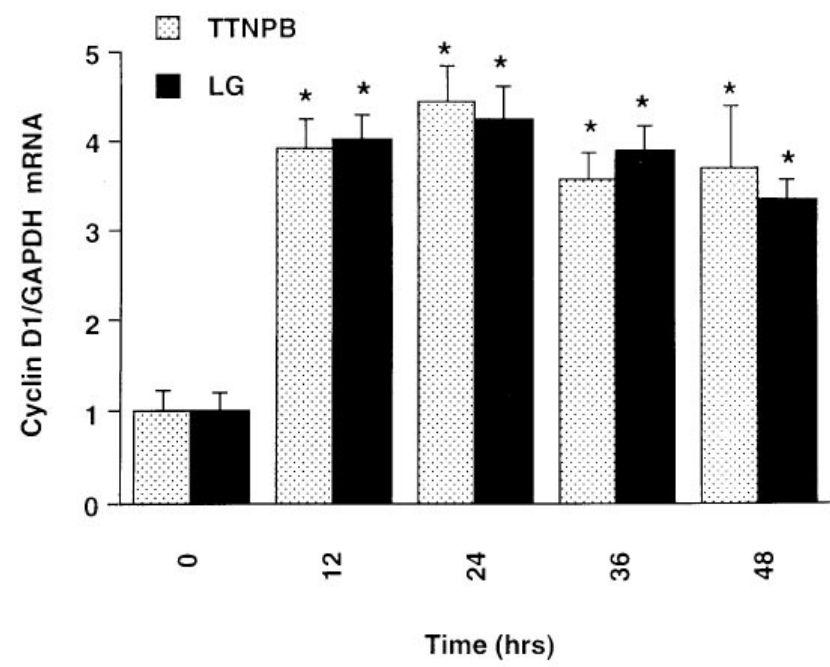

Figure 10. Synthetic RA agonists stimulate cyclin D1 gene expression. Serum-deprived RASM cells were exposed to $2 \times 10^{-6} \mathrm{M}$ TTNPB or LG100153 for the times indicated. Cyclin D1 mRNA was detected as decribed in Fig. 9. Representative autoradiographs are shown in $A$. Data from three independent experiments are presented in $B . * P<0.01$ vs. control.

effects would still require activation of the MEK/ERK cascade for full realization of the mitogenic effect. The locus of ERK interaction with the cell cycle machinery remains undefined in RASM. Interactions of related signaling cascades with the cell cycle machinery (e.g., JNK and p21 [39]) have been reported in other systems, but not in RASM.

It is noteworthy that the inhibitory properties of ATRA appear closely tied to its ability to decrease ET-dependent ERK activity. ATRA has been shown to reduce agonist-stimulated cyclin D activity $(12,13)$ and to increase p21 levels $(14$, $15)$ in other systems, but, to our knowledge, has not been reported to affect ERK activity.

The promitogenic activity of the retinoids seems to derive from a completely different mechanism. ATRA had no effect on basal ERK activity but did promote a significant increment in cyclin D1 mRNA and protein levels. This provides at least one mechanistic explanation for the observed increase in mito-

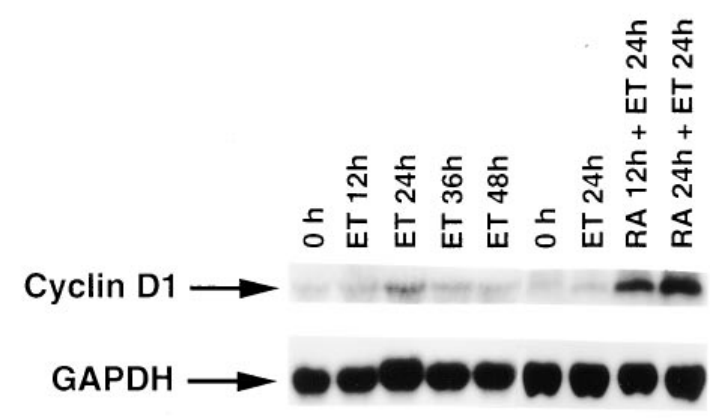

B

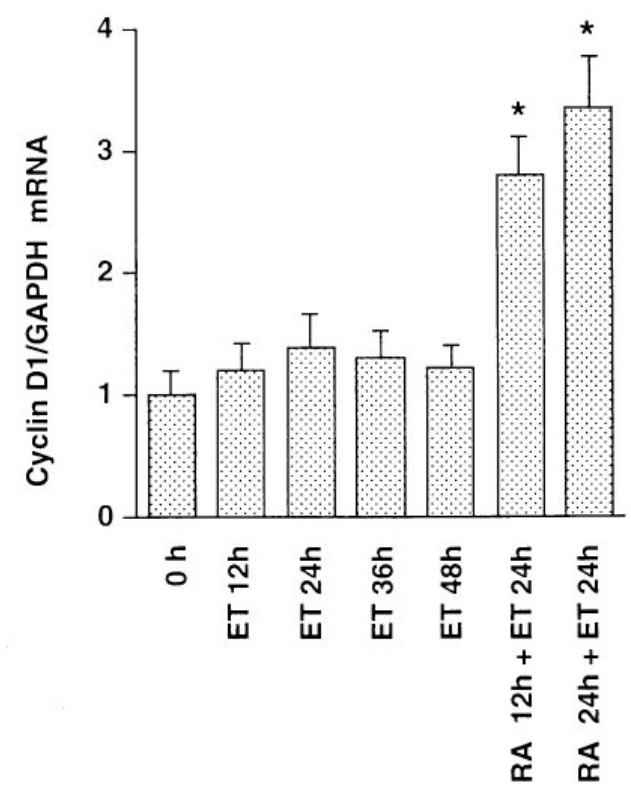

Figure 11. ET does not affect basal or RA-induced cyclin D1 gene expression. Serum-deprived RASM cells were treated with ET $\left(10^{-7}\right.$ $\mathrm{M})$ or ATRA $\left(10^{-8} \mathrm{M}\right)$ for indicated time intervals. Cyclin D1 mRNA was measured as decribed in Fig. 9. Representative autoradiographs are shown in $A$. Data derived from three independent experiments are presented in $B . * P<0.01$ vs. control.

genic activity, but it is unlikely to be the only one. ATRA also increases activity (approximately two- to threefold) of a transiently transfected cyclin $\mathrm{E}$ gene promoter in these RASM cells (data not shown), implying that ATRA may effect a general activation of the G1 cyclin/cdk complexes that guide the cell towards DNA synthesis.

Our studies also imply the presence of a built-in servomechanism to limit the extent of the pro-mitogenic effect. As noted above, this was most marked with the higher $\left(2 \times 10^{-6}\right.$ $\mathrm{M})$ vs. lower $\left(10^{-8} \mathrm{M}\right)$ concentration of ATRA (or synthetic ligand) in that the former, which though more effective in in- 


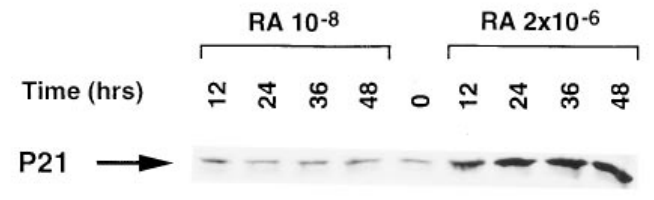

B

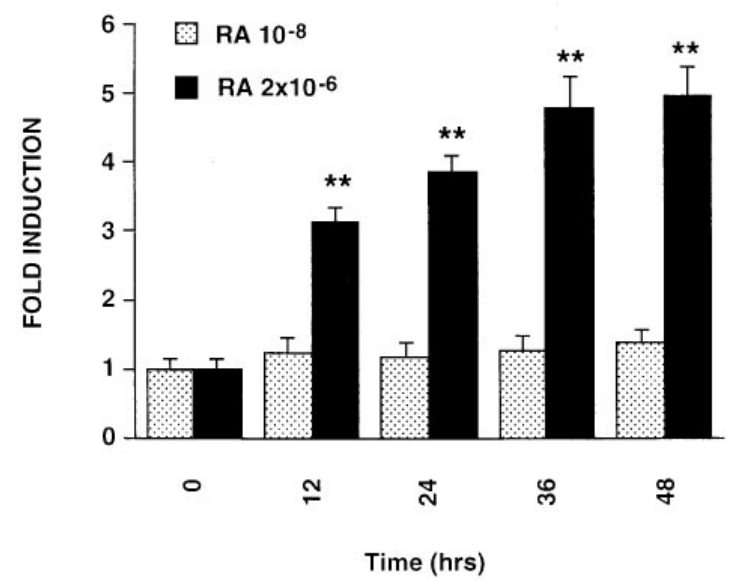

hibiting ET-dependent ERK activity and mitogenesis, was clearly less effective in promoting $\left[{ }^{3} \mathrm{H}\right]$ thymidine incorporation in its own right. This did not reflect different levels of cyclin D1 activation, since these were near equivalent at the two ligand concentrations. Rather, it seems to be due to increased expression of p21 at the higher concentration of ATRA. Thus, it would appear that there are two parallel but independent mechanisms for inhibiting mitogenesis in these RASM cultures, the first involving reductions in agonist-dependent ERK activity and the second related to activation of p21 expression. The relative importance of each of these in a given setting will depend upon the growth status of the cells in the culture and the concentration of ATRA used. Several studies have reported retinoid-dependent stimulation of p21 gene expression $(14,15)$, and a retinoid-sensitive regulatory element has been described in the promoter of the p21 gene (15). It remains unclear, however, why p21 stimulation should require higher concentrations of ATRA in this particular setting. The $K_{\mathrm{d}}$ of RAR for ATRA is in the nanomolar range (18). Higher concentrations of ATRA are required for activation of RXR (vs. RAR) since this agonist requires isomerization to 9-cis RA, the true ligand for RXR (19), for complete activation of that receptor. However, both the RAR- and RXR-selective ligands were effective in stimulating DNA synthesis in these cells and, in both instances, the lower concentration was more effective
Figure 12. Effect of ATRA on $\mathrm{p} 21$ expression in RASM cells. Serum-deprived RASM cells were treated with ATRA for the times indicated. Cell extracts were generated and $\mathrm{p} 21$ protein was detected by Western blot analysis as described in Fig. 9. Representative experiments are presented in $A$. Data derived from six independent experiments are shown in $B$. In separate experiments RASM cells were transfected with $5 \mu \mathrm{g}$ of the WWP-p21-Luc reporter. $24 \mathrm{~h}$ after transfection, medium was changed to DME/ serum substitute for $24 \mathrm{~h}$. At that point cells were exposed to different concentrations of ATRA in the same medium for defined periods of time. Cells were collected, extracts were generated, and luciferase activity was measured as described in Methods. Data presented were obtained from four different experiments $(C)$. ${ }^{*} P<0.05$, $* * P<0.01$ vs. control. than the higher. It remains possible that the difference could reflect differential availability of the individual ligands to and/ or stability in the relevant intracellular compartment (i.e., nuclei) in these cells vs. other systems examined to date.

It should also be noted that the RAR- and RXR-selective ligands, though equally effective in reducing ET-dependent $\left[{ }^{3} \mathrm{H}\right]$ thymidine incorporation, did not effect equivalent decreases in ET-dependent ERK activity. This implies that ERK-independent pathways (e.g., p21 activation) contribute a significant portion of the antimitogenic activity in this setting and imply a redundancy in the available mechanisms responsible for controlling smooth muscle cell proliferation.

In summary, retinoids capable of binding to either RAR or RXR are capable of inhibiting ET-stimulated DNA synthesis and cell replication in RASM cells. These effects appear to be tied to suppression of ET-dependent ERK activity in this model. When used alone in quiescent cells, retinoids activate, rather than suppress, DNA synthesis, a finding that correlates with increased expression of cyclin D1. The latter effect is, to some degree, truncated by coexistent stimulation of the cdk inhibitor $\mathrm{p} 21$. These seemingly divergent properties of the retinoids in vascular smooth muscle cells suggest that careful scrutiny of their in vivo effects is necessary to assess their true therapeutic potential in the management of disorders involving the vascular wall. 


\section{Acknowledgments}

We are grateful to Dr. C. Sherr, S. Rosenthal, and R. Heymann who provided plasmids and/or reagents used in this study. We are also deeply indebted to Dr. J. Wu for his advice during the early phases of these experiments and to Dr. H. Yuen for providing assistance with the measurements of cell number.

This study was supported by National Institutes of Health grants HL-45637 and HL-35753.

\section{References}

1. Lammer, E.J., D.T. Chen, R.M. Hoar, N.D. Agnish, P.J. Benke, J.T. Braun, C.J. Curry, P.M. Fernhoff, A.W. Grix, I.T. Lott, et al. 1985. Retinoic acid embryopathy. N. Engl. J. Med. 313:837-841.

2. Sucov, H.M., E. Dyson, C.L. Gumeringer, J. Price, K.R. Chien, and R.M. Evans. 1994. RXR $\alpha$ mutant mice establish a genetic basis for vitamin A signaling in heart morphogenesis. Genes Dev. 8:1007-1018.

3. Kastner, P., J.M. Grondona, M. Mark, A. Gansmuller, M. LeMeur, D. Deimo, J.L. Vonesch, P. Dolle, and P. Chambon. 1994. Genetic analysis of RXR alpha developmental function: convergence of RXR and RAR signaling pathways in heart and eye morphogenesis. Cell. 78:987-1003.

4. Mendelsohn, C., D. Lohnes, D. Decimo, T. Lufkin, M. LeMeur, P. Chambon, and M. Mark. 1994. Function of the retinoic acid receptors (RARs) during development. Development. 120:2749-2771.

5. Dyson, E., H.M. Sucov, S.W. Kubalak, G.W. Schmid-Schonbein, F.A. DeLano, R.M. Evans, J. Ross, Jr., and K.R. Chien. 1995. Atrial-like phenotype is associated with embryonic ventricular failure in retinoid $\mathrm{X}$ receptor $\alpha-1-$ mice. Proc. Natl. Acad. Sci. USA. 92:7386-7390.

6. Gruber, P.J., S.W. Kubalak, T. Pexieder, H.M. Sucov, R.M. Evans, and K.R. Chien. 1996. RXR alpha deficiency confers genetic susceptibility for aortic sac, conotruncal, atrioventricular cushion and ventricular muscle defects in mice. J. Clin. Invest. 98:1332-1343.

7. Wu, J., M. Garami, T. Cheng, and D.G. Gardner. 1996. 1,25 (OH $)_{2}$ Vita$\min \mathrm{D}_{3}$ and retinoic acid antagonize endothelin-stimulated hypertrophy of neonatal rat cardiac myocytes. J. Clin. Invest. 97:1577-1588.

8. Zhou, M.D., H.M. Sucov, R.M. Evans, and K.R. Chien. 1995 Retinoiddependent pathways suppress myocardial cell hypertrophy. Proc. Natl. Acad. Sci. USA. 92:7391-7395.

9. Miano, J.M., S. Topouzis, M.J. Majesky, and E.N. Olson. 1996. Retinoid receptor expression and all-trans retinoic acid-mediated growth inhibition in vascular smooth muscle cells. Circulation. 93:1886-1895.

10. Warrell, R.P. Jr., H. de The, Z.Y. Wang, and L. Degos. 1993. Acute promyelocytic leukemia. N. Engl. J. Med. 329:177-189.

11. Esgleyes-Ribot, T., R.A. Chandraratna, D.A. Lew-Kaya, J. Sefton, and M. Duvic. 1994. Response of psoriasis to a new topical retinoid, AGN 190168.J. Am. Acad. Dermatol. 30:581-590.

12. Langenfeld, J., H. Kiyokawa, D. Sekula, J. Boyle, and E. Dmitrovsky. 1997. Posttranslational regulation of cyclin D1 by retinoic acid: A chemoprevention mechanism. Proc. Natl. Acad. Sci. USA. 94:12070-12074.

13. Zhou, Q., M. Stetler-Stevenson, and P.S. Steeg. 1997. Inhibition of cyclin $\mathrm{D}$ expression in human breast carcinoma cells by retinoids in vitro. Oncogene. 15:107-115.

14. Naka, K., H. Yokozaki, T. Domen, K. Hayashi, H. Kuniyasu, W. Yasui, R. Lotan, and E. Tahara. 1997. Growth inhibition of cultured human gastric cancer cells by 9-cis-retinoic acid with induction of cdk inhibitor Waf1/Cip1/ Sdi1/p21 protein. Differentiation. 61:313-320.

15. Liu, M., A. Iavarone, and L.P. Freedman. 1996. Transcriptional activation of the human $\mathrm{p} 21^{\text {Wafl/Cip } 1}$ gene by retinoic acid receptor. J. Biol. Chem. 271: $31723-31728$.

16. Babajko, S., and M. Binoux. 1996. Modulation by retinoic acid of insulin-like growth factor (IGF) and IGF binding protein expression in human SKN-SH neuroblastoma cells. Eur. J. Endocrinol. 134:474-480.

17. Standeven, A.M., M. Escobar, R.L. Beard, Y.D. Yuan, and R.A. Chandraratna. 1997. Mitogenic effect of retinoid X receptor agonists in rat liver. Biochem. Pharmacol. 54:517-524.
18. Kastner, P., M. Mark, and P. Chambon. 1995. Nonsteroid nuclear receptors: What are genetic studies telling us about their role in real life? Cell. 83: 859-869.

19. Heyman, R.A., D.J. Mangelsdorf, J.A. Dyck, R.B. Stein, G. Eichele, R.M. Evans, and C. Thaller. 1992. 9-cis retinoic acid is a high affinity ligand for the retinoid X receptor. Cell. 68:397-406.

20. Bauer, R.F., L.O. Arthur, and D.L. Fine. 1976. Propagation of mouse mammary tumor cell lines and production of mouse mammary tumor virus in serum free medium. In Vitro. 12:558-563.

21. Matsushime, H., M.F. Roussel, R.A. Ashmun, and C.J. Sherr. 1991. Colony-stimulating factor 1 regulates novel cyclins during the G1 phase of the cell cycle. Cell. 65:701-713.

22. Fort, P., L. Marty, M. Piechaczyk, S.E. Sabrouty, C. Dani, P. Jeanteur, and J.M. Blanchard. 1985. Various rat adult tissues express only one major mRNA species from the glyceraldehyde-3-phosphate dehydrogenase multigenic family. Nucleic Acids Res. 13:1431-1442.

23. Cao, L., J. Wu, and D.G. Gardner. 1995. Atrial natriuretic peptide suppresses the transcription of its guanylyl cyclase-linked receptor. J. Biol. Chem. 270:24891-24897.

24. Mitsuhashi, T., R.C. Morris, Jr., and H.E. Ives. 1991. 1,25-dihydroxyvitamin $\mathrm{D}_{3}$ modulates growth of vascular smooth muscle cells. J. Clin. Invest. 87: 1889-1895.

25. Fujitani, Y., H. Ninomiya, T. Okada, Y. Urade, and T. Masaki. 1995. Suppression of endothelin-1-induced mitogenic responses of human aortic smooth muscle cells by interleukin-1 beta. J. Clin. Invest. 95:2474-2482.

26. Masood, I., K.E. Porter, and N.J. London. 1997. Endothelin-1 is a mediator of intimal hyperplasia in organ culture of human saphenous vein. $\mathrm{Br} . \mathrm{J}$. Surg. 84:499-503.

27. Cadwallader, K., J. Beltman, F. McCormick, and S. Cook. 1997. Differential regulation of extracellular signal-regulated protein kinase 1 and Jun $\mathrm{N}$-terminal kinase 1 by $\mathrm{Ca}^{2+}$ and protein kinase $\mathrm{C}$ in endothelin-stimulated Rat-1 cells. Biochem. J. 321:795-804.

28. Waskiewicz, A.J., and J.A. Cooper. 1995. Mitogen and stress response pathways: MAP kinase cascades and phosphatase regulation in mammals and yeast. Curr. Opin. Cell Biol. 7:798-805.

29. Sherr, C.J. 1996. Cancer cell cycles. Science. 274:1672-1677.

30. Teixeira, C., and M.A.C. Pratt. 1997. CDK2 is a target for retinoic acidmediated growth inhibition in MCF-7 human breast cancer cells. Mol. Endocrinol. 11:1191-1202.

31. Kawa, S., T. Nikaido, Y. Aoki, Y. Zhai, T. Kumagaya, K. Furihata, S. Fujii, and K. Kiyosawa. 1997. Arotinoid mofarotene (RO40-8757) up-regulates p21 and p27 during growth inhibition of pancreatic cancer cell lines. Int. J. Cancer. 72:906-911.

32. Owens, G.K. 1995. Regulation of differentiation of vascular smooth muscle cells. Physiol. Rev. 75:487-517.

33. Colbert, M.C., D.G. Hall, T.R. Kimball, S.A. Witt, J.N. Lorenz, M.L. Kirby, T.E. Hewett, R. Klevitsky, and J. Robbins. 1997. Cardiac compartmentspecific overexpression of a modified retinoic acid receptor produces dilated cardiomyopathy and congestive heart failure in transgenic mice. J. Clin. Invest. 100:1958-1968.

34. Weber, H., M.L. Webb, R. Serafino, D.S. Taylor, S. Moreland, J. Norman, and C.J. Molloy. 1994. Endothelin-1 and angiotensin-II stimulate delayed mitogenesis in cultured rat aortic smooth muscle cells: Evidence for common signaling mechanisms. Mol. Endocrinol. 8:148-158.

35. Morey, A.K., A. Pedram, M. Razandi, B.A. Prins, R.M. Hu, E. Biesiada, and E.R. Levin. 1997. Estrogen and progesterone inhibit vascular smooth muscle proliferation. Endocrinology. 138:3330-3339.

36. Schieffer, B., H. Drexler, B.N. Ling, and M.B. Marrero. 1997. G proteincoupled receptors control vascular smooth muscle cell proliferation via pp $60^{\text {c-src }}$ and p21 ras. Am. J. Physiol. 272:C2019-C2030.

37. Irons, C.E., M.A. Flynn, L.M. Mok, and E.E. Reynolds. 1996. Endothelin and PDGF enhance arachidonic acid release and DNA synthesis in vascular smooth muscle cells. Am. J. Physiol. 270:C1642-C1646.

38. Whelchel, A., J. Evans, and J. Posada. 1997. Inhibition of ERK activation attenuates endothelin-stimulated airway smooth muscle cell proliferation Am. J. Resp. Cell Mol. Biol. 6:589-596.

39. Shim, J., H. Lee, J. Park, H. Kim, and E.-J. Choi. 1996. A non-enzymatic p21 protein inhibitor of stress-activated protein kinases. Nature. 381:804-807. 